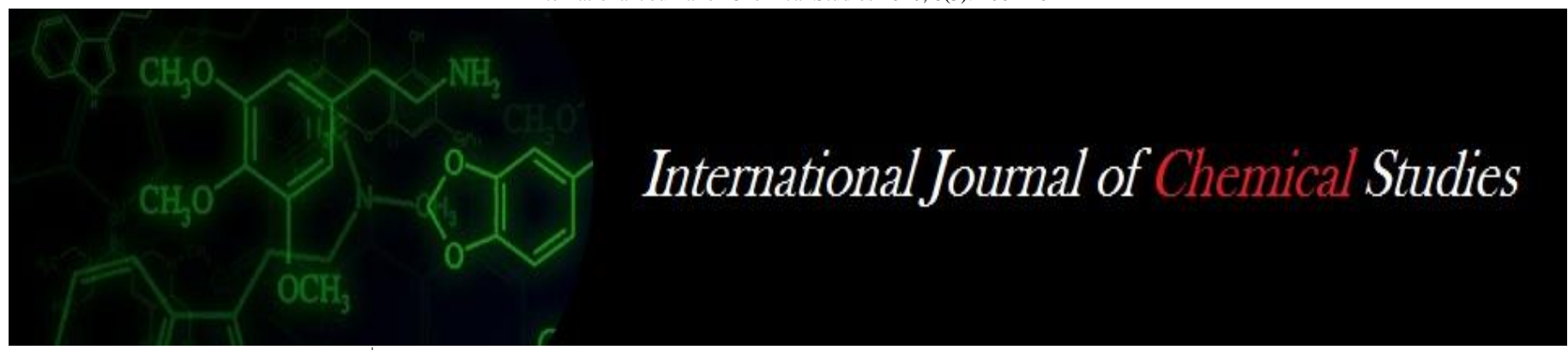

P-ISSN: 2349-8528

E-ISSN: 2321-4902

www.chemijournal.com

IJCS 2020; 8(3): 106-116

(C) 2020 IJCS

Received: 04-03-2020

Accepted: 06-04-2020

Karanjalker Gourish Ranganath College of Horticulture,

University of Horticultural

Sciences, Bagalkot, GKVK Post,

Bengaluru, Karnataka, India

Makki Ramchandra Dinesh

ICAR-Indian Institute of

Horticultural Research,

Hessaraghatta Lake Post,

Bengaluru, Karnataka, India

Kodthalu Seetharamaiah Shivashankara

ICAR-Indian Institute of

Horticultural Research,

Hessaraghatta Lake Post,

Bengaluru, Karnataka, India

Kundapura V Ravishankar ICAR-Indian Institute of Horticultural Research,

Hessaraghatta Lake Post,

Bengaluru, Karnataka, India

Corresponding Author: Karanjalker Gourish Ranganath College of Horticulture, University of Horticultural Sciences, Bagalkot, GKVK Post, Bengaluru, Karnataka, India

\section{Morphological and biochemical characterization of peel of different coloured mango cultivars}

\author{
Karanjalker Gourish Ranganath, Makki Ramchandra Dinesh, Kodthalu \\ Seetharamaiah Shivashankara and Kundapura V Ravishankar
}

DOI: $\underline{\text { https://doi.org/10.22271/chemi.2020.v8.i3b.9211 }}$

\begin{abstract}
Some morphological and biochemical parameters were studied to characterize only mango fruit peel. Morphological evaluation of ripe fruits using mango descriptors revealed considerable variation amongst mango cultivars. Parameters 'L', 'b', 'C' and ' $h$ ' showed strong correlation with carotenoids in peel of different coloured cultivars. Also, Biochemical analysis showed a wide variation amongst different coloured mango cultivars with their changing pattern during ripening. The higher content of total chlorophyll, total carotenoids and anthocyanins were noticed in peel of green, yellow and red coloured cultivars respectively. The presence of small quantities of lycopene was also noticed in peel of these cultivars. Mango peel was found to be associated with a decrease in chlorophyll content and increase in the total carotenoids and total anthocyanin contents during ripening of fruit. This study reports some morphological and biochemical parameters of mango peel helpful in breeding (selection of parents) and processing (peel utilization) of fruits.
\end{abstract}

Keywords: Mango (Mangifera indica L.), peel morphology, peel colour, pigments, ripening

\section{Introduction}

Mango (Mangifera indica L.) is believed to be originated from Indo-Burman region and a wide diversity is available for the breeding of mango. Different coloured mangoes are available and accordingly have been generally categorized into three types viz. green, yellow and red.

Mango peel has been the commodity of interest among the researchers from various fields like human nutrition, biotechnology and pharmacy. Mango peel is a good source of other phytochemicals such as enzymes, vitamin $\mathrm{E}$, vitamin $\mathrm{C}$, cellulose, hemicellulose, lipids, protein and pectin ${ }^{[3,5,37]}$. The antioxidant properties of peel in terms of polyphenols, anthocyanins and carotenoids content implicated its potential utilization in nutraceutical and functional food industry ${ }^{[2,3]}$.

The varieties are developed from germplasm through selection on the basis of parameters like fruit shape, colour, size, flavour, aroma, taste, time of maturity, juice content, total soluble solids, acidity, etc. ${ }^{[36]}$. However, these traits are considered to be the most common and important characters for screening the cultivars that could be used in a selection, as well as those unsuitable could be discarded in breeding programs ${ }^{[26]}$. While selecting parents, preference has to be given for their proper identification through quantitative and qualitative characters. Information on availability of genetic diversity is a prerequisite for undertaking any breeding program [22, 34]. In fact, studying the genetic diversity amongst the conserved germplasm helps to understand the historical background of the elite cultivars that would serve as the backbone for traditional and non-traditional breeding programs ${ }^{[34]}$. Finally, this would help in selection of the elite parents and desirable progenies.

Assessing the biochemical composition of the mango peel in different varieties makes is it possible to select the variety for pharmaceuticals and breeding programs. The mango peel is a bio-waste and the knowledge of its biochemical constituents could substantiate its importance for crop production, processing and marketing of the fruits.

Pronounced inter-varietal composition differences would assist in selection of elite genotypes in future after evaluating their performances. The peel is considered as the major by-product of mango industry and knowing its composition would help in development of appropriate 
utilization strategy. Keeping this in a view, present study was undertaken with the following objectives (i) To characterize morphological parameters of the ripe mango fruits of different coloured cultivars and (ii) To measure colours and different biochemical parameters of peel of coloured mango cultivars during ripening.

\section{Materials and Methods}

Some of the coloured cultivars available in Mango Field Gene Bank of ICAR-Indian Institute of Horticultural Research, Bengaluru were selected for the present study. Fruits of mango cultivars belonging to three coloured groups viz., green (Langra, Amrapali, Hamlet and Bombay No.1), yellow (Arka Anmol, Lazzat Baksh, Peach and Banganapalli) and red (Tommy Atkins, Lalmuni, Gulabi, Janardhan Pasand, Lily and Ostin) were tagged at 50 per cent flowering stage and subsequently fruits were harvested at two dates on the basis of visual maturity indices and previous year data. The first harvest was carried out at $80 \%$ maturity (S1) and second at $100 \%$ (S2) maturity). For ripened stage (S3), fruits were harvested at $100 \%$ maturity and kept for normal ripening after washing with water. Hence, the sampling was done at three stages viz., 80\%, 100\% and ripe stages. Fruits (at least twenty replications at each stage) were subjected for the morphological and colour evaluation before storing peel samples for biochemical analysis. For, biochemical part of the work, fruits were washed, peeled with sterilized peeler, separated from adhering pulp, frozen in liquid Nitrogen and stored at $-80^{\circ} \mathrm{C}$ until analysis.

Fruit characterization for the mango fruits of different cultivars was carried out using the universally accepted standard mango descriptor [13]. The peel colours in terms of 'L', 'a', 'b', 'C' and ' $h$ ' scales at both sides of the fruits were recorded using a colour reader, CR-10 (Minolta Co., Ltd, Osaka, Japan).

The total chlorophyll, carotenoids and lycopene were analyzed by following the spectrophotometric method of Lichtenthaler (1987) ${ }^{[21]}$. Peel sample (5g) was ground completely with acetone until clear extract and the known volume was made up. The extract was dehydrated using anhydrous $\mathrm{Na}_{2} \mathrm{SO}_{4}$ (Sodium Sulphate). The absorbance of the extract was read at $660 \mathrm{~nm}$ and $642 \mathrm{~nm}$. Total chlorophyll contents were then calculated by using the standard value and expressed as $\mu \mathrm{g} / 100 \mathrm{~g}$. Extracted samples used in chlorophyll estimation were carried forward for the total carotenoids and total lycopene estimation. To remove the chlorophylls and unwanted lipids completely, saponification was done with $10 \% \mathrm{KOH}$. The non-aqueous layer was separated and the absorbance was read at $450 \mathrm{~nm}$ for total carotenoids and at $503 \mathrm{~nm}$ for lycopene using spectrophotometer. The standard curve was plotted through serial dilution for standard $\beta$ - carotene and lycopene (Sigma Chem. Co., USA) and total carotenoids and total lycopene contents were calculated in terms of $\mathrm{mg} / 100 \mathrm{gFW}$.

Estimation of anthocyanins was carried out following method of Shivashankara et al. (2010) ${ }^{[35]}$. Using pestle and mortar, peel samples were ground and clear extract was collected, and finally volume was made up to the known volume and absorption was read at $540 \mathrm{~nm}$ using Spectrophotometer. All extractions were carried out at low light to avoid degradation of the anthocyanins. The standard curve was plotted through serial dilution for standard cyaniding and total anthocyanin was calculated and expressed in terms of $\mathrm{mg} / 100 \mathrm{~g}$ FW.

The total flavonoids in mango peel were measured by method of Chun et al. (2003) ${ }^{[9]}$. Peel samples were ground with $80 \%$ methanol in a pestle and mortar and made up the volume to the known volume. Solution was added with $\mathrm{AlCl}_{3}$ and potassium acetate followed by incubation and total flavonoids were estimated by reading the absorbance at $510 \mathrm{~nm}$ calculated using the standard value of catechin expressed in terms of $\mathrm{mg} / 100 \mathrm{~g}$.

Titration method was followed for determining tiratable acidity in terms of per cent citric acid [31]. Five gram of peel sample was ground with distilled water, filtered through muslin cloth and volume was made upto known volume. A Peel extract was titrated against $0.01 \mathrm{~N} \mathrm{NaOH}$ using phenolphthalein as indicator and titratable acidity (\% citric acid) was calculated.

Results were subjected for ANOVA (analysis of variance) under completely randomized design (CRD) at $1 \%$ probability using AGRES software version 3.01 (Pascal International Software Solutions, USA). Pearson's correlation coefficients (r) and p-value were calculated using MS-Excel and online available statistical calculator (http://www.danielsoper.com/statcalc3/) for correlation interpretation between pigments (carotenoids and anthocyanins) and colour values.

\section{Results and Discussion \\ Morphological characterization of ripe fruits of different mango cultivars}

Fourteen mango cultivars belonging to different peel colour categories green, yellow and red revealed considerable variations for 25 fruit descriptors (Table 1). The duration of fruit maturity was long in 'Amrapali' (140 to 154 days) followed by 'Tommy Atkins' (142-150 days), whereas, the shortest duration was observed in cultivars 'Lazzat Baksh' (95 to 123). Hence, as per this study, duration of fruiting in mango vary from 95 to 154 days after fruit set. Similar findings have also been reported by Kalra et al. (1995) in some other cultivars of mango. 
Table 1: Descriptors of colored mango cultivars

\begin{tabular}{|c|c|c|c|c|c|c|c|c|c|c|c|c|c|c|c|}
\hline $\begin{array}{l}\text { Sr. } \\
\text { No. }\end{array}$ & Fruit descriptors & LAN & AMP & HAM & B N.1 & $\mathbf{A A}$ & LZB & PEA & BGNP & TAM & LAL & GUL & JPM & LIL & OST \\
\hline 1 & $\begin{array}{c}\text { Fruiting duration } \\
\text { (days from fruit } \\
\text { set) }\end{array}$ & $103-110$ & $140-154$ & $108-128$ & $119-123$ & $124-135$ & $95-123$ & $110-125$ & $130-145$ & $142-150$ & $112-120$ & $128-130$ & $130-143$ & $125-135$ & $132-142$ \\
\hline 2 & $\begin{array}{l}\text { Fruit bearing } \\
\text { intensity }\end{array}$ & High & High & High & High & High & High & High & High & High & High & High & High & High & High \\
\hline 3 & \begin{tabular}{|l|} 
Fruit length $(\mathrm{cm})$ \\
\end{tabular} & $9.65 \pm 0.84$ & $9.58 \pm 0.82$ & $12.2 \pm 0.7$ & $8.32 \pm 0.36$ & $10.1 \pm 0.35$ & $8.70 \pm 0.20$ & $7.8 \pm 0.24$ & $12.5 \pm 0.33$ & $10.38 \pm 0.6$ & $7.98 \pm 0.28$ & $12.4 \pm 0.72$ & $10.0 \pm 0.6$ & $10.6 \pm 0.8$ & $11.7 \pm 0.4$ \\
\hline 4 & Fruit diameter $(\mathrm{cm})$ & $6.97 \pm 0.41$ & $5.57 \pm 0.32$ & $9.02 \pm 0.69$ & $7.01 \pm 0.60$ & $7.34 \pm 0.57$ & $5.36 \pm 0.21$ & $6.63 \pm 0.48$ & $8.87 \pm 0.53$ & $9.3 \pm 0.48$ & $5.5 \pm 0.29$ & $8.4 \pm 0.49$ & $6.2 \pm 0.66$ & $8.2 \pm 0.4$ & $8.2 \pm 0.4$ \\
\hline 5 & \begin{tabular}{|l|} 
Fruit weight $(\mathrm{g})$ \\
\end{tabular} & $216.64 \pm 29.39$ & $135.94 \pm 12.33$ & $406.44 \pm 94.52$ & $309.42 \pm 76.87$ & $240.34 \pm 5.2$ & $125.79 \pm 11.5$ & $162.4 \pm 20$ & $509 \pm 12.3$ & $419 \pm 35.5$ & $126 \pm 12.4$ & $419.64 \pm 33$. & $234.80 \pm 7.9$ & $377 \pm 41.6$ & $414.9 \pm 35$ \\
\hline 6 & Fruit shape & Elliptic & Oblong & Oblong & Roundish & Oblong & Obtuse & Roundish & Roundish & Round & Oblong & Elliptic & Obovoid & Ovoid & Oblong \\
\hline 8 & Fruit attractiveness & Poor & Poor & Poor & Poor & Excellent & Average & Excellent & Excellent & Excellent & Good & Good & Excellent & Excellent & Good \\
\hline 9 & $\begin{array}{c}\text { Skin color of ripe } \\
\text { fruit }\end{array}$ & Green & Green & Green & Green & Yellow & Yellow & Other & Yellow & Red & Purple & Red & Red & Red & Grey \\
\hline $9 \mathrm{a}$ & Fruit ground color & Green & Green & Green & Green & Yellow & Green & Yellow & Yellow & Green & Green & Green & Green & Green & Green \\
\hline $9 \mathrm{~b}$ & Fruit blush & Other & Other & Other & Other & Other & Other & Orange & other & Purple & Purple & Red & Red & Red & Purple \\
\hline 10 & $\begin{array}{c}\text { Fruit skin thickness } \\
(\mathrm{mm})\end{array}$ & $2.10 \pm 0.06$ & $0.86 \pm 0.05$ & $1.54 \pm 0.21$ & $1.13 \pm 0.007$ & $1.16 \pm 0.05$ & $1.11 \pm 0.37$ & $1.04 \pm 0.04$ & $0.77 \pm 0.30$ & $1.32 \pm 0.122$ & $1.36 \pm 0.05$ & $1.94 \pm 0.27$ & $0.62 \pm 0.11$ & $1.11 \pm 13$ & $0.80 \pm 0.12$ \\
\hline 11 & $\begin{array}{c}\text { Fruit skin surface } \\
\text { texture }\end{array}$ & Smooth & Smooth & Smooth & Rough & Smooth & Rough & Smooth & Smooth & Smooth & Smooth & Rough & Smooth & Smooth & Smooth \\
\hline 12 & $\begin{array}{c}\text { Density of lenticels } \\
\text { on fruit skin }\end{array}$ & Sparse & Medium & Sparse & Medium & Sparse & Medium & Dense & Medium & Sparse & Medium & Intermediate & Dense & Dense & Sparse \\
\hline 14 & \begin{tabular}{|c|}
$\begin{array}{c}\text { Depth of fruit stalk } \\
\text { cavity }\end{array}$ \\
\end{tabular} & Absent & Absent & Absent & Shallow & Absent & Absent & Absent & Medium & Shallow & Absent & Shallow & Absent & Shallow & Absent \\
\hline 15 & $\begin{array}{c}\begin{array}{c}\text { Fruit stalk } \\
\text { attachment }\end{array} \\
\end{array}$ & Weak & Weak & Intermediate & Strong & Weak & Intermediate & Intermediate & Weak & Strong & Weak & Weak & Intermediate & Weak & Weak \\
\hline 16 & $\begin{array}{c}\text { Fruit neck } \\
\text { prominence }\end{array}$ & Slghtly prominent & Prominent & Prominent & Slightly prominent & $\begin{array}{c}\text { Slighly } \\
\text { prominent }\end{array}$ & Absent & Prominent & Absent & \begin{tabular}{|c|} 
Slightly \\
prominent
\end{tabular} & Absent & Absent & $\begin{array}{c}\text { Very } \\
\text { prominent }\end{array}$ & $\begin{array}{c}\text { Slighlty } \\
\text { prominent }\end{array}$ & $\begin{array}{c}\text { Slighlty } \\
\text { prominent }\end{array}$ \\
\hline 17 & $\begin{array}{c}\text { Slope of fruit } \\
\text { ventral shoulder }\end{array}$ & $\begin{array}{l}\text { Ending in long } \\
\text { curve }\end{array}$ & $\begin{array}{c}\text { Sloping } \\
\text { abruptly }\end{array}$ & Ending in long curv & Ending in long curve & $\begin{array}{l}\text { Ending in } \\
\text { long curve }\end{array}$ & $\begin{array}{c}\text { Sloping } \\
\text { abruptly }\end{array}$ & $\begin{array}{l}\text { Ending in } \\
\text { long curve }\end{array}$ & $\begin{array}{l}\text { Ending in } \\
\text { long curve }\end{array}$ & $\begin{array}{c}\text { Rising and } \\
\text { then rounded }\end{array}$ & $\begin{array}{l}\text { Ending in } \\
\text { long curve }\end{array}$ & $\begin{array}{c}\text { Sloping } \\
\text { abruptly }\end{array}$ & $\begin{array}{l}\text { Slopping } \\
\text { abruptly }\end{array}$ & $\begin{array}{l}\text { Ending in } \\
\text { long curve }\end{array}$ & $\begin{array}{c}\text { Sloping } \\
\text { abruptly }\end{array}$ \\
\hline 18 & Fruit beak type & Perceptile & Pointed & Perceptile & Perceptile & Pointed & Prominent & Perceptile & Perceptile & Mammiform & Pointed & Perceptile & Pointed & Perceptile & Pointed \\
\hline 19 & Fruit sinus type & Absent & Shallow & Absent & Shallow & Shallow & Absent & Shallow & Shallow & Shallow & Absent & Absent & Absent & Absent & Absent \\
\hline 20 & Fruit skin waxiness & Waxy & Waxy & Waxy & Waxy & Waxy & Waxy & Waxy & Waxy & Waxy & Waxy & Waxy & Waxy & Waxy & Waxy \\
\hline 21 & $\begin{array}{c}\begin{array}{c}\text { Skin color of ripe } \\
\text { fruit }\end{array} \\
\end{array}$ & Green & Green & Green & Green & Yellow & Yellow & Yellow & Yellow & Red & $\begin{array}{l}\text { Green with } \\
\text { red blush }\end{array}$ & $\begin{array}{l}\text { Green with } \\
\text { red blush }\end{array}$ & $\begin{array}{l}\text { Green with } \\
\text { red blush }\end{array}$ & Red & $\begin{array}{c}\text { Green with } \\
\text { purple patches }\end{array}$ \\
\hline 22 & $\begin{array}{c}\text { Pulp color of ripe } \\
\text { fruit }\end{array}$ & Golden yellow & Yellow orange & Yellow orange & Yellow & $\begin{array}{l}\text { Yellow } \\
\text { orange }\end{array}$ & $\begin{array}{l}\text { Golden } \\
\text { yellow }\end{array}$ & $\begin{array}{l}\text { Golden } \\
\text { yellow }\end{array}$ & Yellow & Yellow & $\begin{array}{l}\begin{array}{l}\text { Gloden } \\
\text { yellow }\end{array} \\
\end{array}$ & Yellow & Light yellow & Yellow & Orange \\
\hline 23 & $\begin{array}{c}\text { Pulp texture of ripe } \\
\text { fruit }\end{array}$ & Intermediate & Intermediate & Soft & Intermediate & Inetermediate & Firm & Intermediate & Intermediate & Firm & Intermediate & Firm & Intermediate & Intermediate & Firm \\
\hline 24 & $\begin{array}{c}\text { Adherence of fruit } \\
\text { skin to pulp }\end{array}$ & Intermediate & Free & Firm & Intermediate & Free & Free & Intermediate & Strong & Intermediate & Firm & Strong & Intermediate & Strong & Inetermediate \\
\hline 25 & $\begin{array}{c}\text { Quantity of latex } \\
\text { oozing from } \\
\text { peduncle }\end{array}$ & High & Low & Medium & Medium & Medium & Medium & Medium & High & Medium & Medium & High & High & Medium & Low \\
\hline
\end{tabular}

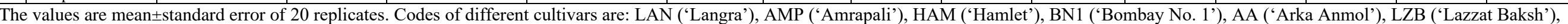

PEA ('Peach'), BGNP ('Banganapalli'), TAM ('Tommy Atkins'), LAL ('Lalmuni'), GUL ('Gulabi'), JPM ('Janardhan Pasand'), OST ('Ostin') and ('Lily') 
Table 2: Various color parameters evaluated by Minolta colorimeter for peel colors of different colored cultivars of mango at fully ripe stage.

\begin{tabular}{|c|c|c|c|c|c|}
\hline Cultivar & 'L' & 'a' & 'b' & ' $C$ ' & 'h' \\
\hline Langra & $52.54 \pm 2.14 b c$ & $-10.40 \pm 0.67 f$ & $27.22 \pm 2.65 \mathrm{cde}$ & $31.66 \pm 3.11 \mathrm{ef}$ & $108.66 \pm 4.12 \mathrm{a}$ \\
\hline Amrapali* & $50.36 \pm 2.59 \mathrm{bcd}$ & $-8.66 \pm 2.55 f$ & $28.60 \pm 5.30 \mathrm{bcd}$ & $29.50 \pm 4.82 \mathrm{def}$ & $108.32 \pm 8.60 \mathrm{a}$ \\
\hline Hamlet & $53.86 \pm 1.89 \mathrm{~b}$ & $-13.02 \pm 2.00 \mathrm{f}$ & $34.54 \pm 2.45 b$ & $36.12 \pm 2.77 \mathrm{e}$ & $111.08 \pm 2.94 \mathrm{a}$ \\
\hline Bombay No. 1 & $50.20 \pm 1.47 \mathrm{efg}$ & $-10.40 \pm 0.71 f$ & $25.30 \pm 0.51 \mathrm{ef}$ & $29.99 \pm 3.22 \mathrm{~g}$ & $106.30 \pm 5.46 \mathrm{a}$ \\
\hline Arka Anmol* & $62.86 \pm 3.55 a$ & $13.46 \pm 1.33 \mathrm{c}$ & $48.86 \pm 3.78 \mathrm{a}$ & $51.18 \pm 1.67 \mathrm{a}$ & $74.32 \pm 2.67 \mathrm{~b}$ \\
\hline Lazzat Baksh & $63.72 \pm 3.87 \mathrm{a}$ & $10.54 \pm 3.26 \mathrm{~cd}$ & $43.24 \pm 3.37 \mathrm{a}$ & $43.12 \pm 1.32 b$ & $76.00 \pm 4.17 \mathrm{~b}$ \\
\hline Peach & $61.58 \pm 3.46 \mathrm{a}$ & $10.56 \pm 2.62 \mathrm{~cd}$ & $46.74 \pm 3.99 \mathrm{a}$ & $49.08 \pm 5.86 \mathrm{ab}$ & $77.30 \pm 3.58 \mathrm{~b}$ \\
\hline Banganapalli & $66.00 \pm 2.27 \mathrm{a}$ & $6.20 \pm 2.99 \mathrm{de}$ & $48.98 \pm 5.48 \mathrm{a}$ & $49.32 \pm 3.71 \mathrm{ab}$ & $84.02 \pm 2.40 \mathrm{~b}$ \\
\hline Tommy Atkins & $46.04 \pm 4.3 \mathrm{def}$ & $13.60 \pm 5.79 a$ & $29.36 \pm 4.40 \mathrm{bcd}$ & $27.26 \pm 6.492 \mathrm{~cd}$ & $51.08 \pm 15.41 \mathrm{~cd}$ \\
\hline Lalmuni & $44.10 \pm 5.73 \mathrm{def}$ & $33.96 \pm 5.23 \mathrm{ab}$ & $20.48 \pm 12.09 \mathrm{bc}$ & $39.20 \pm 4.19 \mathrm{fg}$ & $31.94 \pm 13.11 \mathrm{c}$ \\
\hline Gulabi & $42.28 \pm 4.79 \mathrm{ef}$ & $20.26 \pm 12.51 \mathrm{a}$ & $21.88 \pm 6.93 \mathrm{ef}$ & $31.80 \pm 13.16 \mathrm{~cd}$ & $38.68 \pm 9.04 \mathrm{e}$ \\
\hline Janardhan Pasand* & $45.76 \pm 7.85 \mathrm{fg}$ & $29.92 \pm 4.97 b$ & $28.12 \pm 8.02 \mathrm{def}$ & $39.34 \pm 5.40 \mathrm{ef}$ & $50.20 \pm 12.37 \mathrm{de}$ \\
\hline Ostin & $38.98 \pm 2.13 \mathrm{~g}$ & $30.96 \pm 2.78 \mathrm{a}$ & $15.46 \pm 1.93 \mathrm{f}$ & $35.20 \mathrm{de}$ & $31.00 \pm 4.01 \mathrm{e}$ \\
\hline Lily & $43.60 \pm 3.74 \mathrm{cde}$ & $12.80 \pm 10 \mathrm{e}$ & $19.53 \pm 7.56 \mathrm{cde}$ & 24.50ef & $57.09 \pm 20.48 b$ \\
\hline SEd & 2.49 & 3.33 & 3.59 & 3.37 & 5.95 \\
\hline $\mathrm{CD}(\mathrm{p}<0.01)$ & 6.64 & 8.90 & 9.59 & 8.99 & 15.96 \\
\hline
\end{tabular}

*Some data of three varieties viz. Amrapali, Arka Anmol and Janardhan Pasand have been published by Karanjalker et al. (2017) ${ }^{[15]}$. Analysis was carried out with at least 20 replications, SEd: Standard Error deviation, CD: critical difference at $P<0.01 \% \mathrm{~s}$

The significant variation for the fruit size could be noticed in terms of length and diameter of the fruits of different cultivars. The highest length was observed in case of

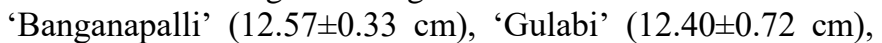
'Hamlet' $(12.22 \pm 0.7 \mathrm{~cm})$ and 'Ostin' $(11.78 \pm 0.4 \mathrm{~cm})$ and the least was in 'Peach' $(7.8 \pm 0.24 \mathrm{~cm})$. However, highest diameter at the broader sides was observed in 'Tommy Atkins' $(9.30 \pm 0.48 \mathrm{~cm})$, 'Hamlet' $(9.02 \pm 0.69 \mathrm{~cm})$ and 'Banganapalli' $(8.87 \pm 0.53 \mathrm{~cm})$ and lowest in 'Lazzat Baksh' $(5.36 \pm 0.21 \mathrm{~cm})$. The significant variation in length and diameter of the fruits among cultivars like 'Tommy Atkins' also indicated distinct shapes of elliptic, oblong, obtuse, roundish, obovoid, oblong and ovoid natures of mango fruits. The bigger sized and heavier fruits were observed in cultivars 'Hamlet', 'Gulabi', 'Tommy Atkins', 'Ostin', Lily, 'Langra', 'Banganapalli' and 'Bombay No.1'. In contrary, cultivars 'Peach', 'Lazzat Baksh', 'Amrapali' possessed smaller sized fruits, whereas, medium sized was observed in 'Arka Anmol' and 'Janardhan Pasand'.

A wide variation for different descriptors viz. fruit length (ranged from 7.8 to $12.57 \mathrm{~cm}$ ), fruit diameter $(5.36$ to 9.30 $\mathrm{cm})$, fruit weight (125.79 to $509.58 \mathrm{~g}$ ), fruit shape (elliptic to roundish), apex shape (acute to round), density of lenticels on fruit skin (sparse to dense), stalk insertion (oblique to vertical), stalk depth (absent to shallow), beak types (pointed to perceptile), sinus types (absent to shallow), skin thickness (0.62 to $2.10 \mathrm{~mm}$ ) and adherence of skin to pulp (firm to strong) was observed amongst cultivars (Table 1). The presence of waxiness was also noticed on the peel of all cultivars. Variations for these parameters were also reported by researchers ${ }^{[32]}$.

In general, fruit weight (125.79 to $509.58 \mathrm{~g}$ ) and fruit length ( 7.8 to $12.57 \mathrm{~cm}$ ) observed in the present study (Table 1) is similar to the values recorded by Singh et al. (2012) ${ }^{[36]}$ where it varied from 50.3 to $380.4 \mathrm{~g}$ for fruit weight and 6.03 to $12.52 \mathrm{~cm}$ for fruit length amongst 28 unexploited mango varieties. A wide variability has been reported for fruit weight and size in different mango cultivars in India ${ }^{[14,22]}$. Similarly, considerable diversity has been reported for Mexican mangoes for fruit traits viz. length, width, weight, etc. ${ }^{[12]}$.

The other parameters like fruit shapes (elliptic to round), apex shape (acute to round), density of lenticels on fruit skin (sparse to dense), fruit stalk insertion (oblique and vertical), depth of fruit stalk cavity (absent to shallow), fruit beak type (pointed to perceptile) and fruit sinus type (absent to shallow) explains the presence of a wide diversity among mango genotypes (Table 1). The peel thickness varied from 0.62 to $2.10 \mathrm{~mm}$ amongst the cultivars studied here. Pulp adherence to the peel (skin) varied from free to strong among cultivars at ripe stage. In majority of cultivars, pulp colour was observed to be golden yellow. The texture of pulp varied from soft to firm. Also, sap ooziness varied from low to high within the cultivars. These descriptors presented shows significant features of ripe mango fruits of different coloured cultivars of mango.

Regarding colour, apart from typical green, yellow and red colours, blushes of these types were also observed (Table 1). In cultivars 'Gulabi', 'Janardhan Pasand' and 'Lily', red blushes were present on the shoulders of ripe fruits. However, purple blushes were observed in case of 'Tommy Atkins', 'Lalmuni' and 'Ostin' fruits. Fruit of cultivar 'Peach' were of yellow ground colour with orange blushes. In the present investigation, fourteen cultivars belonging to three coloured peel categories (green, yellow and red) were observed to have yellow, yellowish red or orange-red blush on the peel, especially on shoulders and tips. Some of the cultivars were recorded with green ground colours as well. Many of researchers like Singh et al. (2012), Begum et al. (2012) and Dinesh et al. (2012) [6, 10, 36] have made significant contributions in improving our understanding on this aspect. They mainly reported the presence of yellow, greenish yellow, reddish yellow, yellow orange, reddish as well as blushed natures of mango peel colours. The peel colour varied from yellow to reddish yellow amongst accession of Andhra Pradesh ${ }^{[6]}$.

Morphological characterization is a prerequisite for observing diversity, germplasm conservation and utilization in breeding programmes ${ }^{[6]}$. Considering the variability observed during the present investigation, for various morphological traits among the mango cultivars from earlier reports, the diversity could be utilized for processing and crop improvement programmes.

\section{Mango peel colours at different ripening stages}

The lightness (' $L$ ') depicts the higher values (100) towards whiteness and lower (0) values towards blackishness. Among the different coloured cultivars evaluated at ripe stage, highest lightness (L) was observed in 'Banganapalli' (66.00) that was on par with 'Lazzat Baksh' (63.72), 'Arka Anmol' (62.86) and 'Peach' (61.58) (Table 2). These cultivars are yellow 
coloured. However, low values of ' $\mathrm{L}$ ' were recorded in case of red coloured cultivars. Hence, lightness was more in yellow followed by green and red coloured mango peel. Retention in ' $\mathrm{L}$ ' values was evident in mango peel during ripening in case of the green and red coloured cultivars (Fig. 1a). However, in yellow coloured cultivars, the lightness increased during ripening process.

The hunter ' $a$ ' value explains the contrasting redness (positive values) and greenness (negative values) for the test commodity. All yellow and red coloured cultivars at ripe stage showed positive values and contrast in case of the green coloured cultivars (Table 2). The highest ' $a$ ' values were observed in red coloured 'Lalmuni' (33.96) and 'Ostin' (30.96). The least and negative values were observed in case of green coloured cultivars (-8.66 to -13.02$)$ indicating their colour retention. In red coloured cultivars, the drastic increase in ' $a$ ' value was observed during ripening (Fig. 1b). Also the increase in 'a' values was observed in case of yellow cultivars that changed significantly from negative to positive values during ripening. This suggests their changing colours from green. But in green coloured cultivars, negative values were retained during the ripening of fruits indicating their retention of green colour.

The ' $b$ ' values withstand for the critical views on the contrasting yellow (positive values) and blue (negative values) of colours. Significant higher values for yellow were observed in yellow coloured cultivars that ranged from 43.24 (cv. Lazzat Baksh) to 48.98 ( $c v$. Banganapalli) (Table 2), whereas, the least values were obtained for red coloured 'Lily' (15.46). Generally, 'b' values were higher in yellow coloured followed by green and red coloured varieties. During ripening of the fruits, drastic increase in the values of ' $b$ ' by 20 folds from the mature stage was observed in yellow colour indicating development of yellow colour during ripening (Fig. 1c). However, values of ' $b$ ' either remained unchanged or decreased during ripening in other coloured cultivars.

Chroma values explain the intensity or purity of dominant colours. The ' $c$ ' values were significantly higher in case of the yellow coloured cultivar that indicated their purity of yellow colour (Table 2). The 'c' values were significantly higher in case of the yellow coloured cultivar that indicated their purity of yellow colour (Table 2). The highest value for chroma (c) was noticed in yellow coloured $c v$. 'Arka Anmol' (51.18) and significantly lower ' $c$ ' value was noticed in red coloured $c v$. 'Tommy Atkins' (27.26). No significant variation among the red and green colours indicates that there are mixture of the other colours. Increased 'c' values were evident in yellow coloured cultivars during ripening, whereas the constant expression was observed in other types of the colours (Fig. 1d).

Hue angle indicates the dominant colours of the test commodity implicated through values of $0^{\circ}$ as red, $90^{\circ}$ as yellow, $180^{\circ}$ as green and $270^{\circ}$ as blue colours. The higher ' $h$ ' values were observed for green coloured cultivars ('Langra', 'Amrapali', 'Hamlet' and 'Bombay No.1') followed by yellow and red types (Table 2). The highest hue angle was observed for the green coloured 'Hamlet' (111.08) and least in red coloured 'Ostin' (31.0) indicating their respective dominant green and red colour. At initial maturity stages ( $80 \%$ and $100 \%$ maturity) in yellow coloured cultivars the higher values were obtained showing its green nature, however later showed decrease during ripening at ripe stage. Hence, decrease in ' $h$ ' values was noticed in yellow and red coloured cultivars. However, almost constant values of ' $h$ ' were recorded in green cultivars (Fig. 1e).
The values obtained in the present study were similar with the values observed for 'L', 'a', 'b', 'c' and 'h' by Nambi et al. (2015) ${ }^{[28]}$ for two yellow coloured cultivars viz. 'Alphonso' and 'Banganapalli'. Ayala-Silva et al. (2005) [4] reported colour parameters for different coloured mango cultivars 'Keitt', 'Mamita', 'Sandersha', 'Tommy Atkins', 'Tyler Premier' and 'White Alfonso'. Similar studies on colour evaluation were also undertaken in mango by Ornelas-Paz et al. (2008) ${ }^{[30]}$ where they observed values for ' $L$ ' $(47.3 \pm 1.4$ to $71.4 \pm 0.6)$, 'a' $(9.8 \pm 1.5$ to $23.6 \pm 1.3)$,' b' $(21.0 \pm 2.4$ to $43.8 \pm 0.4)$, 'C' $(29.14 \pm 1.0$ to $47.4 \pm 0.3)$ and ' $h$ ' $(39.6 \pm 4.1$ to $74.0 \pm 0.3)$. Also, Muengkaew et al. (2016) ${ }^{[27]}$ observed 38.37, 3.37, 26.75 and 82.81 values for ' $L$ ', ' $a$ ', 'b' and ' $h$ ' respectively for mango peel of red coloured $c v$. 'Manhachanok'.

For the 14 cultivars used in the present study, colour parameters showed differential values during ripening (Table 2). Such developmental pattern was also observed in the cherry ${ }^{[7]}$. The peel colour is an important quality parameter of fruit that appeals to consumer, helps to predict maturity and internal quality ${ }^{[4]}$. In the present study, the colours were evaluated in order to characterize peel of different coloured cultivars using colourimeter. Results revealed significant variations among different groups (green, yellow and red types) studied. The colour variation was also observed within the groups and at different stages of maturity.

\section{Correlation between colour and pigments of mango peel at ripe stage}

Correlation between colour parameters (L, a, b, C, h) and pigments (carotenoids and anthocyanins) of mango peel were worked out to further elaborate our results. Parameter ' $a$ ' $(r=0.738)$ showed high positive correlation with anthocyain contents, while for ' $L$ ' and ' $C$ ' it was negative (Table 3 ). The ' $b$ ' represents colour in terms of positive values for red and negative values for green colours. In red coloured cultivars 'Tommy Atkins', 'Lalmuni', 'Gulabi' and 'Janardhan Pasand 'positive ' $a$ ' values were observed and hence might have showed the positive correlation with anthocyanin contents in mango peel. The hue angle distribution amongst the cultivars was used to illustrate the peel colour and its correlation with anthocyanin and chlorophyll contents ${ }^{[29]}$. The red coloured cultivars showed positive correlation $(0.76 \geq r \geq 0.58)$ for hue angle and anthocyanin contents. Kasim et al (2011) [17] evaluated 12 cultivars of cherry laurel (Prunus laurocerasus L.) fruits for colours and anthocyanins suggested that there were strong correlation of anthocyanins with chromatic parameters $\left(a^{*} b^{*}\right.$, chroma, and hue angle) except for $L^{*}$ value.

Table 3: Pearson's correlation (r) between pigments (carotenoids and anthocyanin) with color values at ripen stage

\begin{tabular}{|l|l|l|}
\hline Color Parameters & Anthocyanin Contents & carotenoid contents \\
\hline
\end{tabular}

\begin{tabular}{|c|c|c|c|c|}
\hline & r-value & significance & r-value & significance \\
\hline 'L' & -0.500 & 0.08 & 0.758 & $0.008^{* *}$ \\
\hline 'a' & 0.738 & $0.011^{*}$ & 0.200 & 0.302 \\
\hline 'b' & 0.0412 & 0.458 & 0.664 & $0.025^{*}$ \\
\hline 'C' & -0.0028 & 0.497 & 0.797 & $0.005^{* *}$ \\
\hline ' $h$ ' & 0.041 & 0.458 & 0.664 & $0.025^{*}$ \\
\hline
\end{tabular}

The correlation values range from -1 to 1 . Asterisk symbol (*) represents the significance of $\mathrm{r}$ values ${ }^{*} p \leq 0.05,{ }^{* *} p \leq 0.01$ and ${ }^{* * *} p \leq$ 0.001

Regarding correlation of colour parameters and carotenoids, there was a positive correlation for all the parameters ' $L$ ' 
$(\mathrm{r}=0.75 ; \quad p<0.008), \quad$ 'a' $\quad(\mathrm{r}=0.200 ; p<0.302), \quad$ 'b' $\quad(\mathrm{r}=0.664 ;$ $p<0.025)$, 'c' $(\mathrm{r}=0.797 ; \mathrm{p}<0.005)$ and ' $\mathrm{h}$ ' $(\mathrm{r}=0.664 ; p<0.025)$ (Table 3). Moreover, the ' $\mathrm{L}$ ' $(\mathrm{r}=0.758 ; \mathrm{p}<0.008)$ and ' $\mathrm{C}$ ' $(\mathrm{r}=0.797 ; p<0.005)$ showed to be highly correlated with the carotenoids. These parameters explain the yellowness of cultivars viz. 'Arka Anmol', 'Lazzat Baksh', 'Peach' and 'Banganapalli' that was observed with high caroetenoids. Hence the positive correlation showed its nature of colours and direct correlation with carotenoids. Ornelas-Paz et al., (2008)[30] correlated various colour parameters ' $L$ ' $(47.3 \pm 1.4$ to $71.4 \pm 0.6)$, 'a' $(9.8 \pm 1.5$ to $23.6 \pm 1.3)$, ' $\mathrm{b}$ ' $(21.0 \pm 2.4$ to $43.8 \pm 0.4)$, 'c' $(29.14 \pm 1.0$ to $47.4 \pm 0.3)$ and ' $h$ ' $(39.6 \pm 4.1$ to $74.0 \pm 0.3)$ which was positively correlated with carotenoid contents of yellow coloured cultivars.

\section{Biochemical analysis of peel of different coloured mango cultivars at ripening stages}

Comparison of total chlorophyll contents in ripe peel of coloured mango cultivars showed significant variation (Table 4). Highest total chlorophyll contents were recorded in peel of green coloured cultivars 'Bombay No. 1' (26.73 $\mu \mathrm{g} / 100 \mathrm{~g}$ FW) 'Amrapali' (13.96 $\mu \mathrm{g} / 100 \mathrm{~g}$ FW), 'Langra' (10.76 $\mu \mathrm{g} / 100 \mathrm{~g}$ FW) and 'Hamlet' $(10.27 \mu \mathrm{g} / 100 \mathrm{~g}$ FW) and lowest was recorded in red coloured cultivar 'Lily' $(0.60 \mu \mathrm{g} / 100 \mathrm{~g}$ FW). The high chlorophyll content $(26.73 \mu \mathrm{g} / 100 \mathrm{~g}$ FW) was observed in green coloured 'Bombay No. 1' and moderate contents was in yellow coloured 'Banganapalli' (13.30 $\mu \mathrm{g} / 100 \mathrm{~g} \mathrm{FW})$ and red coloured 'Lalmuni' $(9.60 \mu \mathrm{g} / 100 \mathrm{~g} \mathrm{FW})$ which was on par with two green coloured cultivars ('Langra' and 'Amrapali'). However, lower concentration was observed in red coloured 'Lily' $(0.64 \mu \mathrm{g} / 100 \mathrm{~g} \mathrm{FW})$ and 'Ostin' $(2.42$ $\mu \mathrm{g} / 100 \mathrm{~g} \mathrm{FW})$ peel. Generally, chlorophyll contents in mango peel were high in green coloured cultivars at ripe stages and varied from $0.67 \mu \mathrm{g} / 100 \mathrm{~g}$ FW (red coloured $c v$. Lily) to 26.73 $\mu \mathrm{g} / 100 \mathrm{~g}$ FW (green coloured $c v$. Bombay No.1) are in agreement with those reported by earlier investigators $[3,19,30$, 39]

The loss of total chlorophyll content was observed in peel during ripening of fruits in coloured cultivars (Fig. 2a). A gradual degradation of total chlorophyll content from 2.5 to
$0.8 \mu \mathrm{g} / 100 \mathrm{~g}$ FW from unripe to ripe stage was also observed by Medlicott et al. (1986) ${ }^{[25]}$ in red coloured $c v$. 'Tommy Atkins'. In the present study, the green coloured mango cultivars were having higher chlorophyll content. The degradation of total chlorophyll contents was observed during ripening indicating its role in imparting peel colour (Fig. 2a). The significant difference for total carotenoids was observed amongst the peel of different coloured cultivars (Table 4). The yellow coloured cultivar 'Arka Anmol' was observed with highest total carotenoids $(54.6 \mathrm{mg} / 100 \mathrm{~g} \mathrm{FW})$ and lowest in red coloured 'Lily' $(2.3 \mathrm{mg} / 100 \mathrm{~g} \mathrm{FW})$. Except for cultivar 'Banganapalli', all other yellow coloured cultivars were superior to other ones for total carotenoids. Yellow coloured 'Banganapalli' which was expected to posess high carotenoids contents because of its yellow colour was observed with moderate carotenoids (12.5 mg/100g FW) which was on-par with some of the red and green coloured cultivars. Total carotenoids were also higher in cultivar 'Amrapali' (green) (24.1 mg/100g FW) even though it is green in colour. Generally, total carotenoids in mango peel were higher in yellow coloured cultivar and it ranged from 2.3 $\mathrm{mg} / 100 \mathrm{~g} \mathrm{FW}$ (red coloured $c v$. Lily) to $54.6 \mathrm{mg} / 100 \mathrm{~g} \mathrm{FW}$ (yellow coloured $c v$. Arka Anmol).

Total carotenoid content varied from 23 to $546 \mu \mathrm{g} / \mathrm{g}$ on fresh weight basis amongst the cultivars studied here (Table 4). This finding is in accordance with the earlier reports by Ajila et al. (2007) ${ }^{[2]}$ and Nordey et al. (2014) ${ }^{[29]}$ and who suggested that total carotenoids in mango peel extracts vary between i.e., 14.37 to $35.9 \mu \mathrm{g} / \mathrm{g} \mathrm{FW}$ and 74 to $436 \mu \mathrm{g} / \mathrm{g} \mathrm{FW}$, respectively. However, another report by the same group of researchers ${ }^{[3]}$ suggested that total carotenoid contents vary between $1400 \mu \mathrm{g} / \mathrm{g}$ ('Badami') and $3945 \mu \mathrm{g} / \mathrm{g} \mathrm{FW}$ ('Raspuri') among yellow coloured mango cultivars. Similarly, Rymbai et al. (2013) ${ }^{[33]}$ reported high variations for total carotenoids (493 to $3,945 \mu \mathrm{g} / \mathrm{g} \mathrm{FW}$ ) in peel of mango. This variation in contents might be due to saponification step that removes some of the carotenoids and other impurities [8]. Saponification was carried out during the present study in order to obtain pure carotenoids and hence it could possibly be the.

Table 4: Various biochemical characters of mango peel of different colored cultivars at fully ripe stage.

\begin{tabular}{|c|c|c|c|c|c|c|c|c|}
\hline Sr. No & Cultivar & $\begin{array}{c}\text { Peel } \\
\text { color }\end{array}$ & $\begin{array}{c}\text { Total } \\
\text { chlorophyll } \\
(\boldsymbol{\mu g} / \mathbf{1 0 0 g} \mathbf{~ F W})\end{array}$ & $\begin{array}{c}\text { Total } \\
\text { carotenoids } \\
(\mathbf{m g} / \mathbf{1 0 0 g} \mathbf{~ F W}) *\end{array}$ & $\begin{array}{c}\text { Total } \\
\mathbf{l y c o p e n e} \\
(\mathbf{m g} / \mathbf{1 0 0 g} \mathbf{F W})\end{array}$ & $\begin{array}{c}\text { Total } \\
\text { anthocyanin } \\
(\mathbf{m g} / \mathbf{1 0 0 g} \mathbf{F W}) *\end{array}$ & $\begin{array}{c}\text { Total flavonoids } \\
(\mathbf{m g} / \mathbf{1 0 0 g} \text { FW })\end{array}$ & $\begin{array}{c}\text { Titratable acidity } \\
(\mathbf{\%} \mathbf{C . A})\end{array}$ \\
\hline 1 & Langra & Green & $10.76 \pm 2.35 \mathrm{c}$ & $18.7 \pm 1.3 \mathrm{f}$ & $0.15 \pm 0.019 \mathrm{ef}$ & $3.14 \pm 0.33 \mathrm{~b}$ & $19.70 \pm 98.19 \mathrm{c}$ & $1.39 \mathrm{a}$ \\
\hline 2 & Amrapali & Green & $13.96 \pm 4.78 \mathrm{~b}$ & $24.1 \pm 6.2 \mathrm{cde}$ & $0.27 \pm 0.04 \mathrm{bc}$ & $5.68 \pm 0.16 \mathrm{ef}$ & $41.06 \pm 2.64 \mathrm{a}$ & $1.28 \mathrm{a}$ \\
\hline 3 & Hamlet & Green & $10.27 \pm 1.14 \mathrm{c}$ & $10.8 \pm 2.9 \mathrm{fh}$ & $0.15 \pm 0.024 \mathrm{efg}$ & $1.24 \pm 0.28 \mathrm{~h}$ & $8.32 \pm 2.50 \mathrm{ef}$ & $1.28 \mathrm{a}$ \\
\hline 4 & Bombay No. 1 & Green & $26.73 \pm 0.29 \mathrm{a}$ & $25.8 \pm 2.6 \mathrm{~cd}$ & $0.40 \pm 0.0033 \mathrm{~b}$ & $7.80 \pm 3.42 \mathrm{de}$ & $9.50 \pm 0.73 \mathrm{ef}$ & $1.17 \mathrm{ab}$ \\
\hline 5 & Arka Anmol & Yellow & $3.13 \pm 0.19 \mathrm{efg}$ & $54.6 \pm 5.0 \mathrm{a}$ & $0.78 \pm 0.018 \mathrm{a}$ & $6.70 \pm 0.26 \mathrm{ef}$ & $10.57 \pm 0.68 \mathrm{def}$ & $1.17 \mathrm{ab}$ \\
\hline 6 & Lazzat Baksh & Yellow & $2.89 \pm 0.20 \mathrm{efg}$ & $28.5 \pm 2.08 \mathrm{bc}$ & $0.27 \pm 0.115 \mathrm{bcd}$ & $1.85 \pm 0.29 \mathrm{~h}$ & $11.24 \pm 0.56 \mathrm{def}$ & $1.28 \mathrm{a}$ \\
\hline 7 & Peach & Yellow & $6.30 \pm 1.14 \mathrm{def}$ & $37.8 \pm 0.188 \mathrm{~b}$ & $0.36 \pm 0.008 \mathrm{~b}$ & $2.41 \pm 0.31 \mathrm{~h}$ & $7.44 \pm 0.41 \mathrm{ef}$ & $1.28 \mathrm{a}$ \\
\hline 8 & Banganapalli & Yellow & $13.30 \pm 0.471 \mathrm{~cd}$ & $12.5 \pm 0.4 \mathrm{fg}$ & $0.19 \pm 0.0057 \mathrm{cde}$ & $4.94 \pm 0.94 \mathrm{f}$ & $5.13 \pm 0.11 \mathrm{f}$ & $0.75 \mathrm{~cd}$ \\
\hline 9 & Tommy Atkins & Red & $3.29 \pm 0.90 \mathrm{efg}$ & $20.9 \pm 0.96 \mathrm{cde}$ & $0.07 \pm 0.069 \mathrm{fgh}$ & $13.08 \pm 0.81 \mathrm{~b}$ & $13.82 \pm 0.59 \mathrm{cde}$ & $0.85 \mathrm{~cd}$ \\
\hline 10 & Lalmuni & Red & $4.88 \pm 1.19 \mathrm{def}$ & $22.91 \pm 0.14 \mathrm{cde}$ & $0.09 \pm 0.092 \mathrm{efg}$ & $12.91 \pm 3.50 \mathrm{~b}$ & $12.93 \pm 1.55 \mathrm{de}$ & $0.96 \mathrm{bc}$ \\
\hline 11 & Gulabi & Red & $9.60 \pm 1.85 \mathrm{cde}$ & $8.65 \pm 2.5 \mathrm{gh}$ & $0.03 \pm 0.035 \mathrm{hi}$ & $10.77 \pm 0.23 \mathrm{bc}$ & $16.66 \pm 0.215 \mathrm{~cd}$ & $0.96 \mathrm{bc}$ \\
\hline 12 & Janardhan Pasand & Red & $3.12 \pm 0.31 \mathrm{efg}$ & $16.2 \pm 2.5 \mathrm{def}$ & $0.16 \pm 0.0051 \mathrm{def}$ & $21.25 \pm 1.07 \mathrm{a}$ & $28.08 \pm 10.98 \mathrm{~b}$ & $1.28 \mathrm{a}$ \\
\hline 13 & Ostin & Red & $2.42 \pm 0.24 \mathrm{~g}$ & $16.1 \pm 0.52 \mathrm{def}$ & $0.04 \pm 0.041 \mathrm{ghi}$ & $9.35 \pm 0.036 \mathrm{~cd}$ & $10.93 \pm 0.87 \mathrm{de}$ & $0.96 \mathrm{bc}$ \\
\hline 14 & Lily & Red & $0.64 \pm 0.131 \mathrm{fg}$ & $2.3 \pm 0.1 \mathrm{~h}$ & $0.05 \pm 0.046 \mathrm{i}$ & $21.74 \pm 1.16 \mathrm{a}$ & $11.98 \pm 0.54 \mathrm{def}$ & $0.64 \mathrm{~d}$ \\
\hline & SEd & & 3.42 & 0.532 & 0.05 & 0.21 & 3.26 & 0.11 \\
\hline & CD $(p<0.01)$ & & 9.02 & 14.7 & 0.14 & 3.36 & 9.01 & 0.31 \\
\hline
\end{tabular}

Some data for total Chlorophyll, carotenoids and anthocyanins has been published by Karanjalker et al. (2018) ${ }^{[16]}$ as supplementary file with different objective. Values are mean \pm standard error of triplicate analysis, SEd: Standard
Error deviation, CD: critical difference at $p<0.01 \%$, *Significance. Titratable acidity was expressed in terms of per cent citric acid (\% C.A). 
reason for lower concentration observed during the present study. One of the yellow coloured $c v$. 'Banganapalli' was having moderate $(12.5 \mathrm{mg} / 100 \mathrm{~g} \mathrm{FW})$ carotenoid contents (Table 4). However, this cultivar was observed with high chlorophyll contents at the fully ripe stage. Another noticeable fact, that green coloured $c v$. 'Amrapali' was recorded with moderate total carotenoid content (24.1 $\mathrm{mg} / 100 \mathrm{~g} \mathrm{FW})$ and high chlorophyll content $(0.013 \mathrm{mg} / 100 \mathrm{~g}$ FW) (Table 4). This indicates the combined action of different pigments for their respective final colours.

During ripening, increase in the carotenoid contents were observed (Fig. 2b) for all coloured cultivars. Drastic rise in total carotenoids from mature $(11.46 \mathrm{mg} / 100 \mathrm{FW})$ to fully ripe $(54.55 \mathrm{mg} / 100 \mathrm{~g} \mathrm{FW})$ stage was noticed in 'Arka Anmol' peel. However, a minimum of two fold increase in carotenoids contents were observed in other cultivars during ripening. Higher carotenoids contents were recorded in yellow coloured cultivars which increased drastically during ripening. The increase in total carotenoids by five folds along with the degradation of chlorophylls and anthocyanins was observed in 'Tommy Atkins' mango peel ${ }^{[25]}$. The similar trend was also observed in the present study. Hence, total carotenoid content in peel of different coloured mango cultivars were characterized and it was higher in yellow coloured cultivars. Also the drastic increase in their contents during ripening indicated their major role in development of yellow colours during ripening.

Similar to total carotenoid contents, significant variation amongst different coloured cultivars were observed for lycopene content (Table 4), wherein, highest lycopene was observed for 'Arka Anmol' (0.78 mg/100g FW) peel. The total lycopene contents in peels of different coloured cultivars varied from 0.03 to $0.78 \mathrm{mg} / 100 \mathrm{~g} \mathrm{FW}$. The yellow coloured cultivars registered for higher lycopene contents. During ripening, drastic increase was observed for total lycopene in all coloured cultivars (Fig. 2c). Similar to total carotenoids, lycopene was synthesized at higher levels in the yellow coloured cultivars that might have contributed to the colouration of peel. The total lycopene contents were higher in yellow coloured cultivars and the present study reports its content in peel of different coloured mango cultivars. Lycopene is even known for its role as antioxidant.

The highest total anthocyanin contents were observed in 'Lily' (21.74 mg/100g FW) which was on par with 'Janardhan Pasand' (21.25 mg/100g FW) and significantly lowest in green coloured 'Hamlet' (1.24 mg/100 FW) (Table 4). The higher anthocyanin contents in peel of yellow $c v$. "Arka Anmol' (6.70 mg/100g FW) and green $c v$. 'Bombay No. 1 $(7.80 \mathrm{mg} / 100 \mathrm{~g} \mathrm{FW})$, showed close values with some red coloured $c v$. 'Ostin' $(9.35 \mathrm{mg} / 100 \mathrm{~g} \mathrm{FW})$. Generally, total anthocyanin contents were significantly higher in red coloured cultivars than other groups (Table 4). Anthocyanins are responsible for red, blue and purple colours [18]. Comparison of their contents at fully ripe fruit stage, amongst different coloured cultivars showed its significantly higher content in red cultivars. Muengkaew et al. (2016) ${ }^{[27]}$ reported total anthocyanin contents of $1.22 \mathrm{mg} / 100 \mathrm{~g} \mathrm{FW}$ in ripe mangoes of red coloured $c v$. 'Mahachanok', while Dorta et al. (2012) ${ }^{[11]}$ reported total anthocyanin content of 0.5 to 1.9 $\mathrm{mg} / 100 \mathrm{~g}$ DW. These reports showed some resemblance with values obtained in the present study (1.24 to $21.74 \mathrm{mg} / 100 \mathrm{~g}$ FW). On the contrary, Ajila et al (2007a) [3] reported considerably higher amounts of total anthocyanin in raw (203 to $326 \mathrm{mg} / 100 \mathrm{~g} \mathrm{FW}$ ) and ripe peel (360 to $565 \mathrm{mg} / 100 \mathrm{~g} \mathrm{FW}$ ) of 'Badami' and 'Raspuri' mangoes.
Significant increase in total anthocyanin contents was noticed in peel of red coloured cultivars (Fig. 2d). However, irregular pattern of either reduction or no significant variation during ripening was evident in other coloured cultivars (green and yellow) except in case of yellow orange coloured cultivar 'Arka Anmol' that showed significant increase from mature $(2.54 \mathrm{mg} / 100 \mathrm{~g} \mathrm{FW})$ to fully ripe $(6.70 \mathrm{mg} / 100 \mathrm{~g} \mathrm{FW})$. Total anthocyanin contents were higher in all red coloured cultivars than other coloured types and content significantly increased during ripening. However, in some cultivars it did not differ during ripening (Fig. 2d). The pattern of anthocyanins during ripening was studied by Medlicott et al. (1986) ${ }^{[25]}$, showed slight reduction of total anthocyanin contents in red coloured var. 'Tommy Atkins'. However, significant increase was observed in the same cultivar in this study. Though significant reduction was observed in some cultivars viz., 'Langra', 'Hamlet' and 'Lazzat Baksh', however the retention of anthocyanins was noticed during the present study. The high content of the total anthocyanins in peel of red coloured cultivars that increased drastically during ripening suggest its role in red colour development.

In the present study, higher anthocyanin content recorded in ripe peel of red coloured cultivars suggested, the role of the anthocyanins in red colouration of peel in mango cultivars. Also a higher content of anthocyanins in yellow orange coloured 'Arka Anmol' suggested the combined action of anthocyanin and carotenoids for its yellow orange colours. Higher anthocyanin content in peel is also of a great value for processing industry as they are important antioxidants beneficial for human health.

The total flavonoid content, evaluated in mango peel at fully ripe stage showed a great variation amongst different coloured cultivars (Table 4). The flavonoids were significantly higher in $c v$. 'Amrapali'. However, no clear pattern could be suggested for flavonoids content as per the classification of mango fruits according to their colours. Total flavonoids content varied between 5.13 and $41.06 \mathrm{mg} / 100 \mathrm{~g}$ FW among the cultivars studied and its content remained constant during the ripening stage, except for 'Amrapali' and 'Janardhan Pasand' (Fig. 1e). Total flavonoid contents were previously reported ${ }^{[13]}$ to be 22.16 and $21.16 \mathrm{mg} / \mathrm{g} \mathrm{DW}$ in unripe and ripe peel, respectively, where there was no significant change during ripening. Also Umamahesh et al. (2016) ${ }^{[38]}$ found flavonoid content vary from 8.7 to $15.6 \mathrm{mg} / \mathrm{g} \mathrm{DW}$ in mango peel.

Flavonoids are important biochemical with nutraceutical property, which are essential for human health. High flavonoid containing 'Amrapali' could be of great use in processing industry, as many products could be prepared from mango peel ${ }^{[1]}$.

Acidity in terms of per cent citric acid values ranged from 0.64 to $1.39 \%$ citric acid (Table 4 ). The acidity per cent was high in green cultivars followed by red and yellow cultivars. During ripening reduction in acidity by almost 50 percent was observed in all the cultivars (Fig. 1f). Drastic reduction (2\% to $0.5 \%$ ) in acidity was observed which later got decreased from initial $80 \%$ maturity to ripen stage. Hence, mango peel were found to be rich in acidity content (Table 4).

Acidity decides the flavor of a product ${ }^{[24]}$ and hence it is an important trait in processing industry. Titratable acidity ranged from 0.64 to 1.39 per cent citric acid among different coloured cultivars of mango (Table 4) and showed reduction during ripening of fruit (Fig.1f). So far, studies were focused on acidity contents in mango pulp. The acidity of ripe mango pulp varied from 0.25 to $1.81 \%{ }^{[36]}$. Considering acidity 
content in the peel, it could be utilized as an ingredient in processing industries. In the present study, mango peel harvested at $80 \%$ and $100 \%$ maturity was observed with high acidity, later it decreased drastically during ripening.

\section{Conclusions}

In this study, mango peel was examined for morphological, colour and biochemical studies in different coloured mango cultivars during ripening. A wide diversity/ variation was observed amongst the different coloured cultivars for various morphological descriptors, colour and biochemical parameters. The colour evaluation revealed the peel colours and its intensity amongst fourteen evaluated cultivars. The differences in green, yellow and red nature of peel colours was demonstrated among mango cultivars through parameters ('L', 'a', 'b', 'c' and ' $h$ '). Also their changing patterns during ripening process are reported here. The higher content of total chlorophyll, carotenoids and anthocyanins were noticed in peel of green, yellow and red coloured cultivars respectively. Mango peel were found to be associated with a decrease of chlorophyll content and increase in the total carotenoid, and total anthocyanin contents during ripening. Total flavonoids in peel of coloured cultivars increased and titratable acidity decreased during ripening of fruit. Hence, this study reports some morphological and biochemical parameters showing wide diversity for mango peel characters amongst coloured cultivars helpful in breeding (selection of parents) and processing (peel utilization) of fruits.
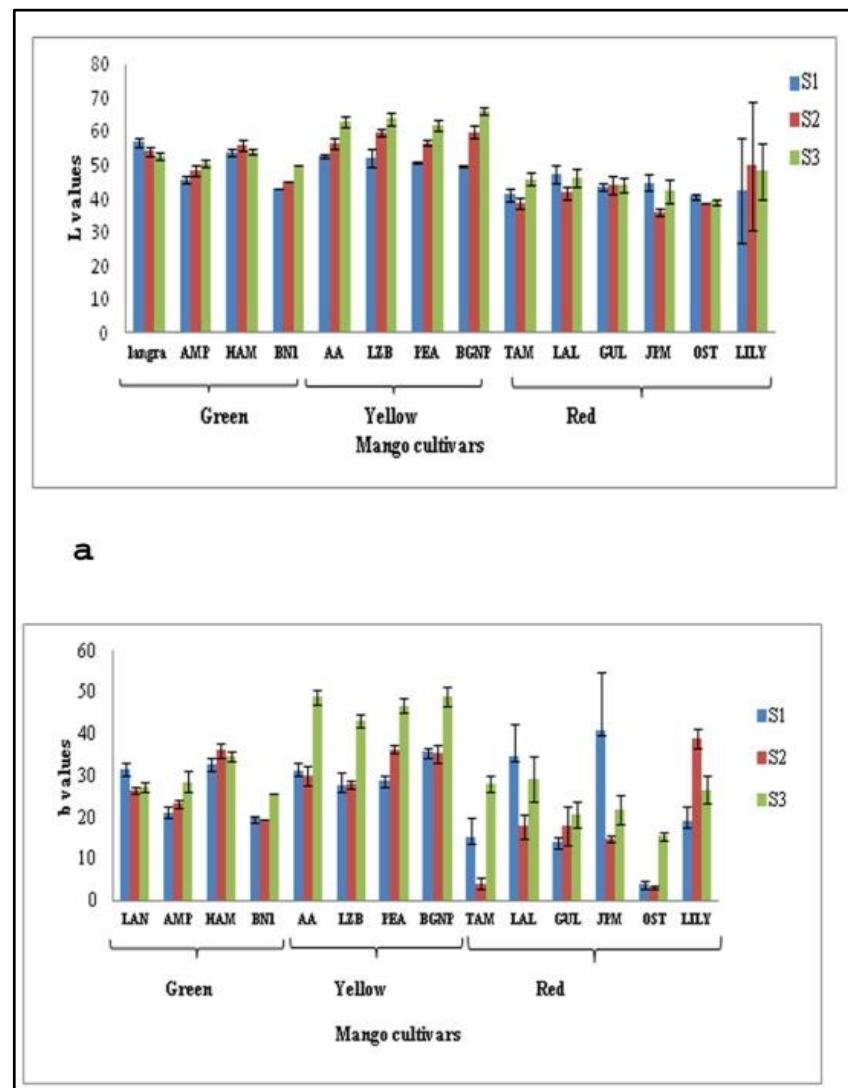

C

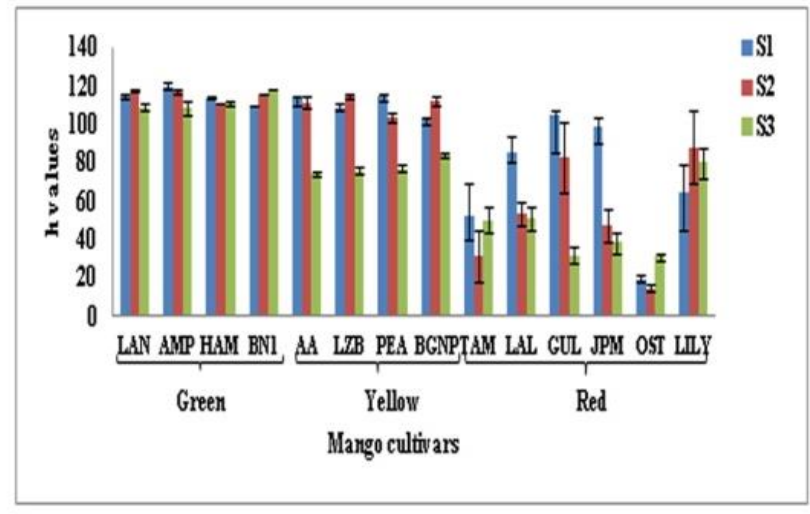

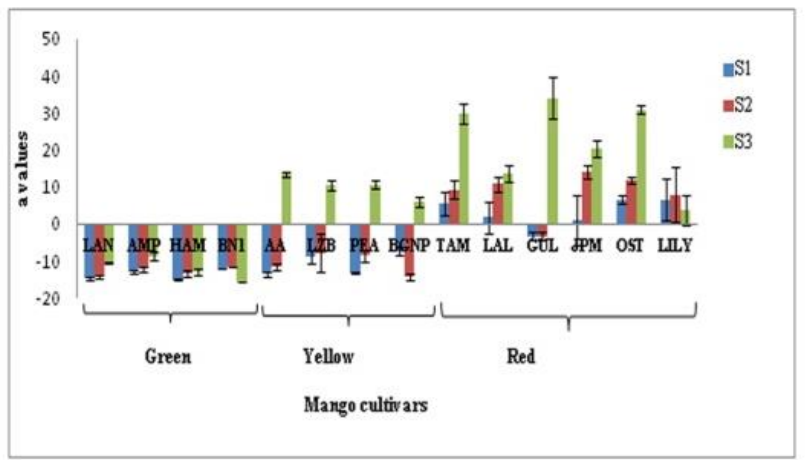

b

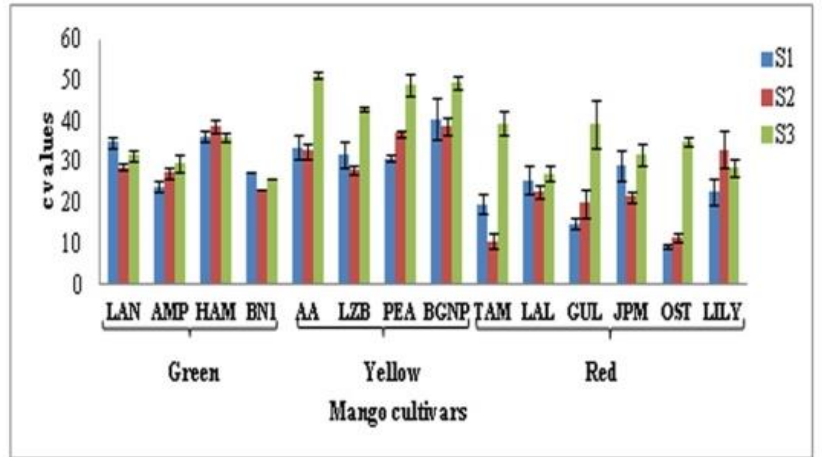

d

Fig 1: Pattern of color changes during ripening. a. L value b. a value c. b value c. C value and d. h (hue angle). S1 (80\% maturity), S2 (100\% maturity) and S3 (fully ripened stage); Codes of different cultivars are: LAN ('Langra'), AMP ('Amrapali'), HAM ('Hamlet'), BN1 ('Bombay No. 1'), AA ('Arka Anmol'), LZB ('Lazzat Baksh'), PEA ('Peach'), BGNP ('Banganapalli'), TAM ('Tommy Atkins'), LAL ('Lalmuni'), GUL ('Gulabi'), JPM ('Janardhan Pasand'), OST ('Ostin') and LILY ('Lily'). Data of three varieties Amrapali, Arka Anmola and Janardhan Pasand have been published by Karanjalker et al., (2017) ${ }^{[15]}$ with different objectives. Bar represents the standard error mean 

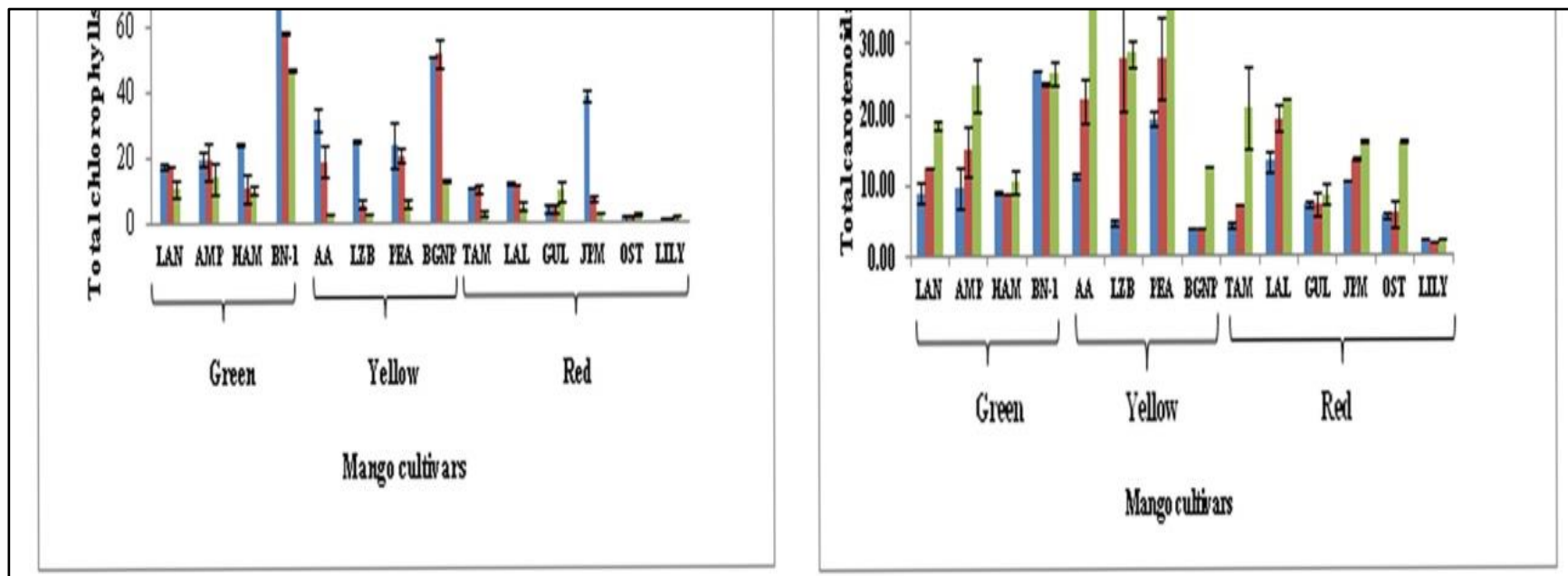

a

$b$

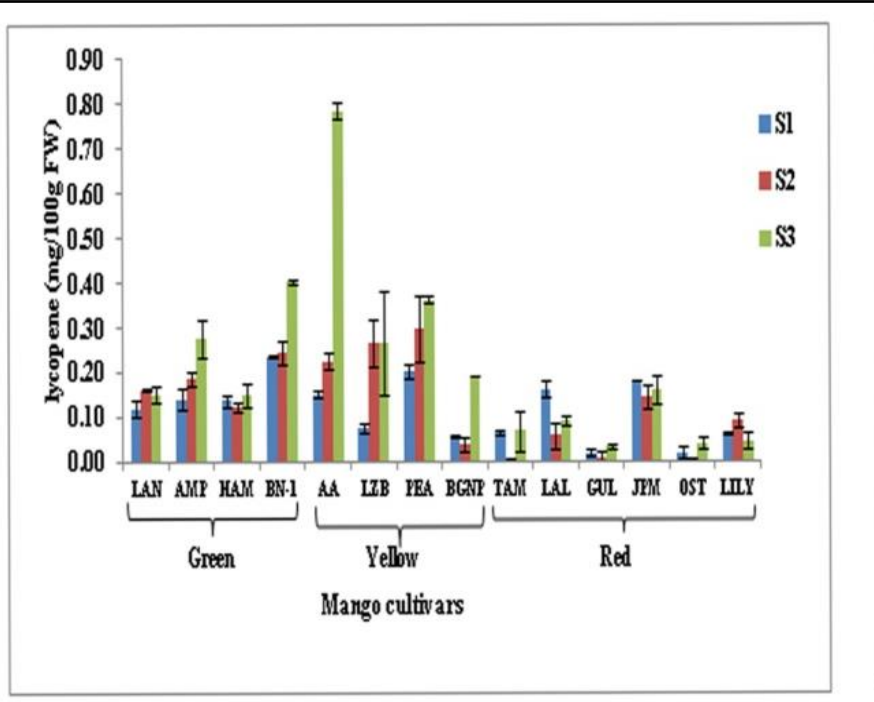

C
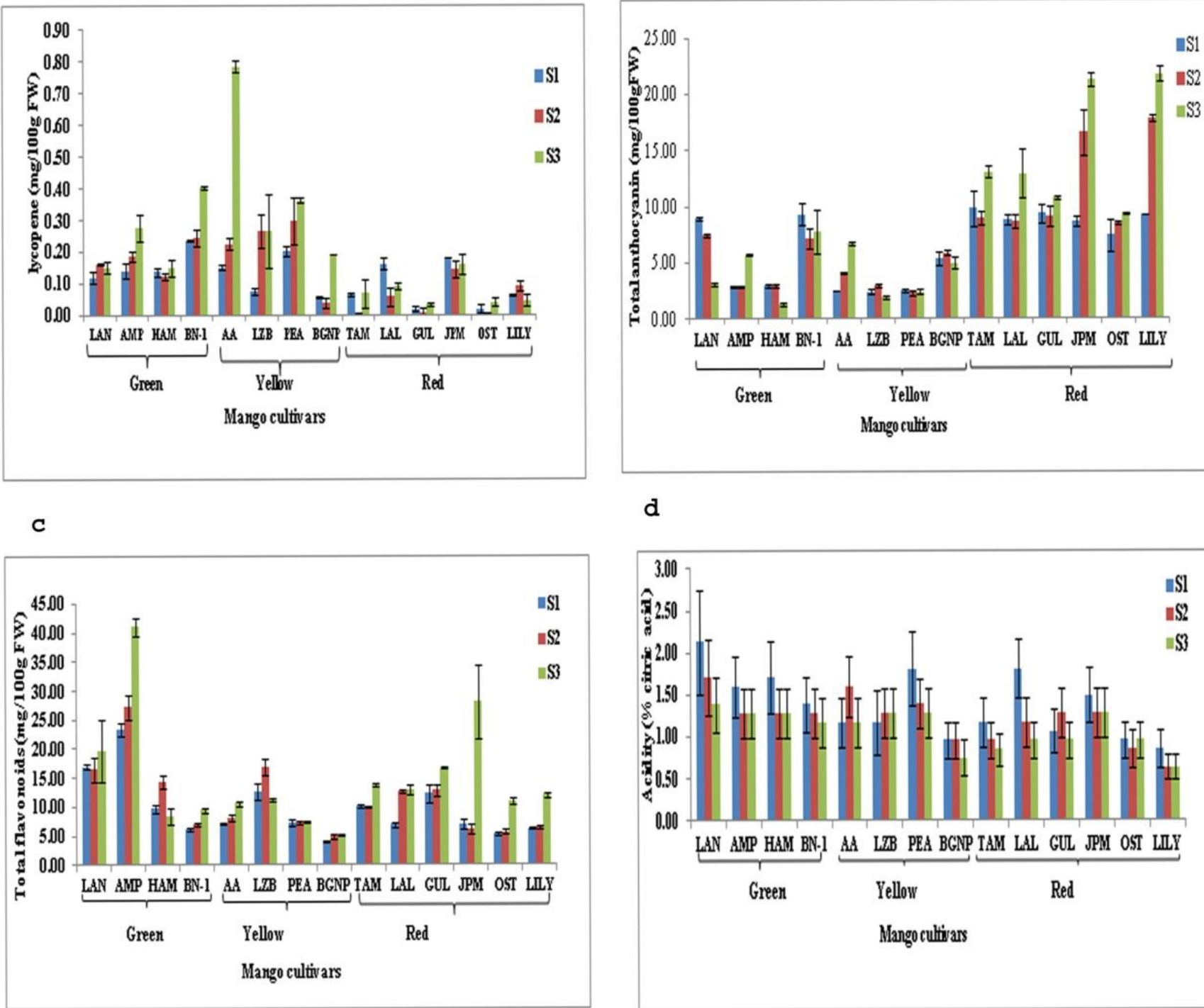

d

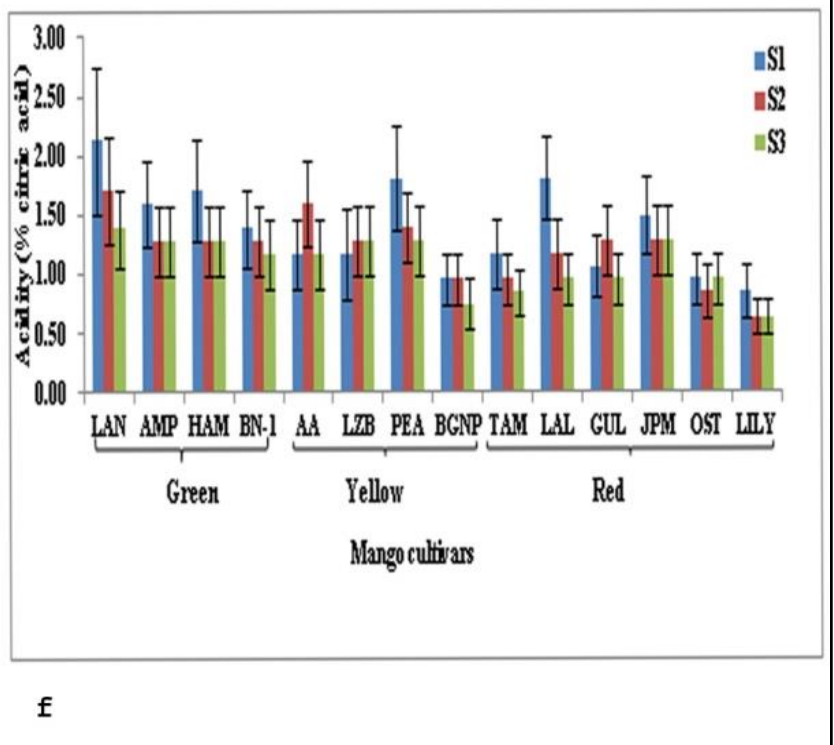

Fig 2: Some data for total Chlorophyll, carotenoids and anthocyanins has been published by Karanjalker et al. (2018) ${ }^{16]}$ as supplementary file with different objective. Pattern of biochemical content changes during ripening. a. Chlorophyll b. Carotenoids c. Lycopene d. Anthocyanin e. Flavonoids, f. Acidity. S1 (80\% maturity), S2 (100\% maturity) and S3 (fully ripened stage); Codes of different cultivars are: LAN ('Langra'), AMP ('Amrapali'), HAM ('Hamlet'), BN1 ('Bombay No. 1'), AA ('Arka Anmol'), LZB ('Lazzat Baksh'), PEA ('Peach'), BGNP

('Banganapalli'), TAM ('Tommy Atkins'), LAL ('Lalmuni'), GUL ('Gulabi'), JPM ('Janardhan Pasand'), OST ('Ostin') and LILY ('Lily'). Bar represents the standard error mean of three replications. 


\section{Acknowledgements}

GRK is thankful to University Grant Commission, New Delhi, for providing financial assistance in the form of Rajiv Gandhi National Fellowship (RGNF-ST-GOA-7140). Authors acknowledge ICAR-IIHR, Bengaluru for providing facility for carrying out this research.

\section{References}

1. Ajila CM, Aalami M, Leelavathi K, Prasada RU. Mango peel powder: a potential source of antioxidant and dietary fiber in macaroni preparations. Innovative Food Science and Emerging Technologies 2010; 11:219-224.

2. Ajila CM, Bhat SG, Prasada RU. Valuable components of raw and ripe peels from two Indian mango varieties. Food Chem. 2007b; 102:1006-1011.

3. Ajila CM, Naidu KA, Bhat SG, Rao UJ. Bio-active compounds and anti-oxidant potential of mango peel extract. Food Chem. 2007a; 105:982-988.

4. Ayala-Silva T, Schnell RJ, Meerow AW, Winterstein MC, Cervantes-Martinez C, Brown JS. Determination of colour and fruit traits of half-sib families of mango (Mangifera indica L.). Proceedings of Florida State Horticultural Society. 2005; 118:253-257.

5. Aziz AN, Wong LM, Bhat R, Cheng LH. Evaluation of processed green and ripe mango peel and pulp flours (Mangifera indica var. chokanan) in terms of chemical composition, antioxidant compounds and functional properties. J Sci. Food Agric. 2012; 92(3):557-633.

6. Begum H, Medagum T, Surapaneni M, Boreddy PR, Sunil A, Javaregowda N et al. Molecular analysis for genetic distinctiveness and relationships of indigenous landraces with popular cultivars of mango (Mangifera indica L.) in Andhra Pradesh, India. The Asian and Australian Journal of Plant Science and Biotechnology 2012; 6(1):24-37.

7. Berta GA, Ana PS, Jose MP, Eunice B, Anne SM. Effect of ripeness and postharvest storage on the evolution of colour and anthocyanins in cherries (Prunus avium L.). Food Chem. 2007; 103:976-984.

8. Cano MP, Ancos B. Carotenoid and carotenoid ester composition in mango fruit as influenced by processing method. J Agric. Food Chem. 1994; 42:2737-2742.

9. Chun OK, Kim DO, Moon HY, Kang HG, Lee CY. Contribution of individual polyphenolics to total antioxidant capacity of plums. J Agric. Food Chem. 2003; 51:7240-7245.

10. Dinesh MR, Vasugi C, Ravishankar KV, Reddy YT. Mango catalogue, ICAR-IIHR, Bengaluru, 2012.

11. Dorta E, Gloria L, Mónica G. Using drying treatments to stabilise mango peel and seed: effect on antioxidant activity. Food Sci. Technol. 2012; 45:261-268.

12. Galvez-Lopez D, Miguel S, Delourdes A, Netzahualcoyotl M. Morphological characterization of native mangos from Chiapas, Mexico. Subtropical Plant Science 2010; 62:18-26.

13. IPGRI. Descriptors for mango (Mangifera indica L.). International Plant Genetic Resources Institute, Rome, Italy, 2006.

14. Jilani MS, Farzana B, Kashif W, Muhammad A. Evaluation of physico-chemical characteristics of mango (Mangifera indica L.) cultivars grown In DI Khan. J. Agric. Res. 2010; 48(2):201-207.

15. Karanjalker GR, Ravishankar KV, Shivashankara KS, DInesh MR, Roy TK, Rao SD. A study on the expression of genes involved in carotenoids and anthocyanins during ripening in fruit peel of green, yellow, and red colored mango cultivars. Applied biochemistry and biotechnology. 2017; 184(1):140-154.

16. Karanjalker GR, Shivashankara KS, Roy TK, Dinesh MR, Geetha GA, Pavithra KC et al. Profiling of anthocyanins and carotenoids in fruit peel of different colored mango cultivars. J Food Sci. Technol. 2018; 55:4566-4577.

17. Kasim R, Sülüsoğlu M, Kasim MU. Relationship between total anthocyanin level and colour of natural cherry laurel (Prunus laurocerasus L.) fruits. African Journal of Plant Science. 2011; 5 (5):323-328.

18. Kayesh E, Lingfei S, Nicholas K, Xin S, Nadira B, Yanping $\mathrm{Z}$ et al. Fruit skin colour and the role of anthocyanin. Acta Physiol. Plant. 2013; 35:2879-2890.

19. Ketsa S, Wandee P, Suranant S. Peel enzymatic activity and colour changes in ripening mango fruit. Plant Physiol. 1999; 154:363-366.

20. Kim AH, Jeong Y, Hyeonji K, Dong-Sun LA, Moonjae $\mathrm{C}$, Hyung-Kyoon $\mathrm{C}$ et al. Antioxidant and antiproliferative activities of mango (Mangifera indica L.) flesh and peel. Food Chem. 2010; 121: 29-436.

21. Lichtenthaler HK. Chlorophylls and carotenoids: pigments of photosynthetic biomembranes. Methods in Enzymology 1987; 148:350-383.

22. Majumder DA, Hassan L, Rahim MA, Kabir MA. Studies on physico-morphology, floral biology and fruit characteristics of mango. J Bangladesh Agril. Univ. 2011; 9(2):187-199.

23. Majumder DA, Hassan L, Rahim MA, Kabir MA. Genetic diversity in mango (Mangifera indica L.) through multivariate analysis. Bangladesh J Agril. Res. 2013; 38(2):343-353.

24. Malundo TM, Shewfelt RL, Ware GO, Baldwin EA. Sugars and acids influence flavor properties of mango (Mangifera indica). J. Am. Soc. Hort. Sci. 2001; 126:115-121.

25. Medlicott A, Mohinder B, Reynolds S. Changes in peel pigmentation during ripening of mango fruit (Mangifera indica Var. Tommy Atkins). Ann. Appl. Biol. 1986; 109:651-656.

26. Meena OP, Bahadur V. Genetic associations analysis for fruit yield and its contributing traits of indeterminate tomato (Solanum lycopersicum L.) germplasm under open field condition. Journal of Agricultural Science. 2015; 7(3):148-163.

27. Muengkaew R, Peerasak C, Warrington I. Changing of physiochemical properties and colour development of mango fruit sprayed methyl jasmonate. Sci. Hortic. 2016; 198:70-77.

28. Nambi VE, Thangavelb K, Manohar DJ. Scientific classification of ripening period and development of colour grade chart for Indian mangoes (Mangifera indica L.) using multivariate cluster analysis. Sci. Hortic. 2015; 193:90-98.

29. Nordey T, Jacques J, Fabrice D, Michel G, Mathieu L. Non-destructive prediction of colour and pigment contents in mango peel. Sci. Hortic. 2014; 171:37-44.

30. Ornelas-Paz JJ, Yahia EM, Gardea AA. Changes in external and internal colour during postharvest ripening of 'manila' and 'ataulfo' mango fruit and relationship with carotenoid content determined by Liquid Chromatography-Apcl+-Time-Of-Flight Mass Spectrometry. Postharvest Biol. Technol. 2008; 50:145152. 
31. Ranganna S. Official methods of analysis (AOAC). $15^{\text {th }}$ Ed., Association of Official Agricultural Chemists, Washington, 1987.

32. Ribeiro IC, Carlos AF, Francisco P. Morphological characterization of mango (Mangifera indica) accessions based on Brazilian adapted descriptors. J Agric. Sci. Technol. 2013; B3:798-806

33. Rymbai H, Srivastav M, Sharma RR, Patel CR, Singh AK. Bio-active compounds in mango (Mangifera indica L.) and their roles in human health and plant defence -a review. J Hortic. Sci. Biotech. 2013; 88(4):369-379.

34. Sherman A, Mo R, Ravit E, Miri B, Mazal I, Michal S et al. (Mangifera indica L.) germplasm diversity based on single nucleotide polymorphisms derived from the transcriptome. BMC Plant Biol. 2015; 15(277):2-11.

35. Shivashankara KS, Jalikop SH, Roy TK. Species variability for fruit antioxidant and radical scavenging abilities in mulberry. International Journal of Fruit Science 2010; 10:355-366.

36. Singh NP, Neelima J, Gurharminder S, Gill PP. Physicochemical characterization of unexploited mango diversity in sub-mountane zone of northern India. Indian J Plant Genet. Resour. 2012; 25(3):261-269.

37. Sogi DS, Siddiq M, Greiby I, Dolan KD. Total phenolics, antioxidant activity, and functional properties of 'tommy atkins' mango peel and kernel as affected by drying methods. Food Chem. 2013; 141:2649-2655.

38. Umamahesh K, Seelam N, Obulam V, Reddy V. Evaluation of antioxidant activity, total phenolics and total flavonoids in peels of five cultivars of mango (Mangifera indica) fruit. Journal of Medicinal Plants Studies 2016; 4(2):200-203.

39. Wang B, Wang J, Liang H, Yi J, Zhang J, Lin L et al. Reduced chilling injury in mango fruit by 2,4dichlorophenoxyacetic acid and the antioxidant response. Postharvest Biol. Technol. 2008; 48:172-181. 